\title{
Analysis of DNA Replication in Fission Yeast by Combing
}

\author{
Divya R. lyer, Shankar Das, and Nick Rhind ${ }^{1}$ \\ Department of Biochemistry and Molecular Pharmacology, University of Massachusetts Medical School Worcester, \\ Massachusetts 01605
}

DNA replication studies based on population experiments give an average estimate of replication kinetics from many cells. This average replication profile masks the stochastic nature of origin firing in eukaryotes, which is revealed by using single-molecule techniques, such as DNA combing. The analysis of replication kinetics by DNA combing involves isolating DNA from cells that have been pulse-labeled with thymidine analogs and stretching it on a silanized coverslip. The analog-labeled patches on the stretched DNA fibers can then be detected using fluorescent antibodies against the analog. Each fiber represents a part of the genome from a single cell; therefore, it is possible to study the variation in behavior of individual origins from one cell to another. Furthermore, each DNA fiber is uniformly stretched, making it possible to measure distances accurately at kilobase resolution. It is also possible to stretch a high density of fibers on coverslips enabling quantitative data collection.

MATERIALS

It is essential that you consult the appropriate Material Safety Data Sheets and your institution's Environmental Health and Safety Office for proper handling of equipment and hazardous material used in this protocol.

RECIPES: Please see the end of this protocol for recipes indicated by $<R>$. Additional recipes can be found online at http://cshprotocols.cshlp.org/site/recipes.

\section{Reagents}

Antibodies (see Table 1)

Antifade mounting medium (Vectashield or ProLong Gold)

$\beta$-agarase (with $10 \times$ buffer, New England Biolabs)

Blocking buffer for DNA combing $<\mathrm{R}>$

BrdU ( $2 \mathrm{~mm}$ stock in water, filter-sterilized and stored at $4^{\circ} \mathrm{C}$ in the dark)

CldU ( $2 \mathrm{~mm}$ stock in water, filter-sterilized and stored at $4^{\circ} \mathrm{C}$ in the dark)

DNA combing enzyme mix $<\mathrm{R}>$

DNA combing plug solution $<\mathrm{R}>$

EDTA (0.5 M, pH 8.0)

$\mathrm{HCl}(2.5 \mathrm{~N})$

IdU ( 2 mM stock in water, titrated with $10 \mathrm{~N} \mathrm{NaOH}$ until IdU dissolves completely, filter-sterilized, and stored at $4^{\circ} \mathrm{C}$ in the dark)

\footnotetext{
${ }^{1}$ Correspondence: nick.rhind@umassmed.edu

From the Fission Yeast collection, edited by lain M. Hagan, Antony M. Carr, Agnes Grallert, and Paul Nurse.

(C) 2018 Cold Spring Harbor Laboratory Press

Cite this protocol as Cold Spring Harb Protoc; doi:10.1101/pdb.prot092015
} 
D.R. Iyer et al.

TABLE 1. Antibodies

\begin{tabular}{llll}
\hline No & Antibody & Detection & Dilution \\
\hline 1 & Mouse anti-BrdU (BD Biosciences 347580) & IdU and BrdU & $1: 20$ \\
2 & Rabbit anti-ssDNA (IBL 18731) & ssDNA & $1: 50$ \\
3 & Rat anti-BrdU (Abcam ab 6326) & CldU and BrdU & $1: 50$ \\
4 & Alexa fluor 488 goat anti-mouse IgG $(\mathrm{H}+\mathrm{L})$, highly cross-adsorbed & Mouse BrdU Ab & $1: 100$ \\
5 & Alexa fluor 350 goat anti-rabbit lgG $(\mathrm{H}+\mathrm{L})$, highly cross-adsorbed & Rabbit ssDNA Ab & $1: 100$ \\
6 & Alexa fluor 594 goat anti-rat IgG $(\mathrm{H}+\mathrm{L})$ & Rat BrdU Ab & $1: 100$ \\
\hline Store all antibodies at $4{ }^{\circ} \mathrm{C}$. Prepare all antibody dilutions in blocking agent. &
\end{tabular}

CldU primary antibody (rat) cross-reacts with the secondary antibody against mouse and rabbit; therefore, always use highly cross-adsorbed secondary antibodies against mouse and rabbit.

\section{$\lambda$-Phage DNA}

Liquid $\mathrm{N}_{2}$

Low-melting point agarose $\left(1.5 \%\right.$ in spheroplasting buffer; dissolved by boiling at $95^{\circ} \mathrm{C}$ and cooled to $\left.42^{\circ} \mathrm{C}\right)$

MES (0.5 M, adjusted to $\mathrm{pH} 5.35$ with $\mathrm{NaOH}$, and filter-sterilized)

Nail polish

$\mathrm{NaOH}(0.5 \mathrm{~N})$

Octenyltrichlorosilane (mixture of isomers 96\%)

PBS $(10 \times$; pH 7.4) <R>

Dilute to $0.1 \times$.

PBST for DNA combing $<\mathrm{R}>$

Proteinase $\mathrm{K}$ buffer $<\mathrm{R}>$

Spheroplasting buffer $<\mathrm{R}>$

Sodium azide $(10 \%)$

S. pombe strain of interest

Super glue

TE buffer $<\mathrm{R}>$

$\mathrm{TE} / \mathrm{YOYO}(0.4 \mu \mathrm{L}$ of YOYO- 1 in $1 \mathrm{~mL} \mathrm{TE})$

YOYO-1

Yeast extract with supplements (YES) $<$ R $>$

Equipment

Beaker (25-mL)

Ceramic holders

Centrifuge (benchtop, for $15-\mathrm{mL}$ and $50-\mathrm{mL}$ tubes)

Centrifuge tubes (15-mL and 50-mL, with conical bottom)

Coplin jars

Coverslips $(22 \times 22 \mathrm{~mm}$, No. 1$)$

Desiccator

DNA Combing System from Genomic Vision (or equivalent)

For instructions on building a combing apparatus, see Gallo et al. (2016).

Epifluorescence microscope with 100× objective and standard DAPI (Ex:360/40 DC:400 Em:460/50), GFP (Ex:470/40 DC:495 Em:525/50), and Texas Red (Ex:560/60 DC:600 Em:615) filter sets

Hemocytometer heat block (for incubations at $37^{\circ} \mathrm{C}, 42^{\circ} \mathrm{C}, 65^{\circ} \mathrm{C}$, and $95^{\circ} \mathrm{C}$ )

Humid chamber

Microslides

Microcentrifuge

Microcentrifuge tubes (1.5-mL; screw-cap)

Microcentrifuge tubes (2-mL; round-bottomed) 
Plasma cleaner (Harrick Basic or equivalent)

Plug mold (four-sided plastic mold, $9 \mathrm{~mm} \times 7 \mathrm{~mm} \times 2 \mathrm{~mm}[\sim 200 \mu \mathrm{L}]$, sealed on the bottom with tape)

Shaking incubator slide holder

Rocking platform

Tubes (2-mL; round-bottomed)

Tubes (15-mL; conical bottom)

Tubes (50-mL; conical bottom)

Water bath $\left(50^{\circ} \mathrm{C}\right)$

\section{METHOD}

Labeling Cells

Single Analog Labeling

1. Grow strain of interest in $100 \mathrm{~mL}$ of YES medium in a $500 \mathrm{~mL}$ conical flask at $30^{\circ} \mathrm{C}$ (or at lower temperature if using a temperature-sensitive strain) with shaking at $200 \mathrm{rpm}$ to a concentration of $4 \times 10^{6}-1 \times 10^{7}$ cells $/ \mathrm{mL}(\mathrm{OD}=0.2-0.5)$.

Uptake of the thymidine-analog label requires yeast cells integrated with hENT1/tk (Hodson et al. 2003; Sivakumar et al. 2004).

2. Add the required concentration of analog and incubate at $30^{\circ} \mathrm{C}$, with shaking at $200 \mathrm{rpm}$ for the required time.

If the analog is added to G2 cells to incorporate the label in the subsequent $S$ phase, then $0.5 \mu \mathrm{m}$ analog (BrdU or CldU or IdU) is usually sufficient, because the cells have ample time to take up the analog, phosphorylate and incorporate it. However, for a short pulse of 5-10 min, use $2 \mu \mathrm{m} \mathrm{CldU}$ or $20 \mu \mathrm{m} I d U$ for single-analog labeling. The concentration of analog used depends on the length of the labeling period. The longer the labeling time, the lower is the concentration needed. The disparity in concentration between $C l d U$ and $I d U$ is because the $C l d U$ antibody is more sensitive than the IdU Ab.

3. At the end of analog labeling place the culture on ice and add ice-cold sodium azide to a final concentration of $0.1 \%$. Transfer an appropriate volume of culture to a $50 \mathrm{~mL}$ conical bottom tube so as to pellet $10^{8}-2 \times 10^{8}$ cells $(\mathrm{OD}=5-10)$ by centrifugation at $4000 \mathrm{~g}$, for $2 \mathrm{~min}$, at $4^{\circ} \mathrm{C}$. Remove supernatant and transfer cells to a $1.5 \mathrm{~mL}$ screw cap tube. Spin for $30 \mathrm{sec}$ at max speed in a microcentrifuge, remove any remaining supernatant and freeze cells in liquid $\mathrm{N}_{2}$ for at least $10 \mathrm{~min}$. Use cells immediately or store at $-80^{\circ} \mathrm{C}$ until needed.

\section{Double Analog Labeling}

4. Grow strain of interest as in Step 1.

5. Add CldU to a final concentration of $0.5 \mu \mathrm{M}$ (for G2-phase cells) or $2 \mu \mathrm{M}$ (for a short pulse of 5$10 \mathrm{~min}$ ) and then add a $10 \times$ amount (relative to the CIdU concentration used) of IdU and incubate at $30^{\circ} \mathrm{C}$, with shaking at $200 \mathrm{rpm}$ for the required time. For a short pulse, label for $10-12 \mathrm{~min}$.

In yeast cells, once the analog gets phosphorylated it cannot be washed out. Therefore, the second analog has to be added at high concentrations to dilute out the first analog. We routinely label cells in mid-S phase for 5 min with $2 \mu \mathrm{M}$ Cld $U$ and chase with $20 \mu \mathrm{m}$ IdU for $10 \mathrm{~min}$. This gives sufficient labeled events (500-700 forks in $25 \mathrm{Mb}$ of DNA) to reliably estimate various parameters of replication kinetics.

6. At the end of analog labeling pellet cells as in Step 3.

Plug Preparation and Cell Wall Digestion

For plug preparation, always use $2 \mathrm{~mL}$ round-bottomed microcentrifuge tubes to avoid damage to plugs.

7. Pellet $1 \times 10^{8}-2 \times 10^{8}$ cells from a mid-log phase culture labeled with analog as in Steps 1-3 or 4-6. 
D.R. Iyer et al.

8. Wash pellet twice with $1 \mathrm{~mL}$ spheroplasting buffer in a $2 \mathrm{~mL}$ round-bottomed microcentrifuge tube. Resuspend cells gently with a pipette, and centrifuge at $5000 \mathrm{~g}$ for $1 \mathrm{~min}$, at room temperature.

9. Add $150 \mu \mathrm{L}$ of DNA combing enzyme mix to the washed pellet. Mix well and incubate for $5 \mathrm{~min}$ in a $37^{\circ} \mathrm{C}$ heat block.

10. Add $150 \mu \mathrm{L}$ of $1.5 \%$ LMP agarose (cooled to $42^{\circ} \mathrm{C}$ ) using a cut off $200 \mu \mathrm{L}$ tip and mix well.

11. Immediately dispense $150 \mu \mathrm{L}$ into each well of the plug mold (two wells per sample) and leave for $20-30 \mathrm{~min}$ at $4^{\circ} \mathrm{C}$ to solidify.

12. Place the two plugs in a single tube and add $1 \mathrm{~mL}$ of DNA combing plug solution.

13. Incubate the plugs for at least $6 \mathrm{~h}$ (or up to $9 \mathrm{~h}$ ) in a $37^{\circ} \mathrm{C}$ heat block.

Proteinase K Treatment

14. Transfer the plugs into a new $2 \mathrm{~mL}$ round-bottomed tube containing $1 \mathrm{~mL}$ Proteinase $\mathrm{K}$ buffer and incubate overnight in a $50^{\circ} \mathrm{C}$ water bath.

15. Replace the Proteinase K buffer roughly every $12 \mathrm{~h}$. Continue the Proteinase K treatment for $60 \mathrm{~h}$. Change the Proteinase K buffer a total of five times.

Make fresh Proteinase $K$ buffer for each change.

TE Washes

16. Remove the buffer and transfer the plugs to a $15 \mathrm{~mL}$ conical bottom tube.

17. Wash plugs twice for $2 \mathrm{~h}$ each time with $10 \mathrm{~mL} \mathrm{TE}+1 \mathrm{~mL} 0.5 \mathrm{~m}$ EDTA pH 8.0 with gentle rocking at room temperature.

18. Wash plugs twice for $2 \mathrm{~h}$ each time with $10 \mathrm{~mL}$ TE with gentle rocking at room temperature.

The plugs can be stored at $4^{\circ} \mathrm{C}$ in TE for many months until needed.

Melting Plugs

19. Place one-half or one plug in a $2 \mathrm{~mL}$ round-bottomed microcentrifuge tube.

20. Add $500 \mu \mathrm{L}$ TE/YOYO, $480 \mu \mathrm{L} 0.5 \mathrm{~m}$ MES pH 5.35 and up to $1.4 \mathrm{~mL} \mathrm{H}_{2} \mathrm{O}$.

The $\mathrm{pH}$ of MES is extremely critical for combing. It determines the density of DNA that will stick to coverslips and their degree of stretching. Titrate the $p H$ of MES using $\lambda$ DNA. Prepare several combing solutions of $\lambda$ DNA with MES buffer of varying $\mathrm{pH}$. Add $200 \mathrm{ng} \lambda \mathrm{DNA}$ to $500 \mu \mathrm{L}$ TE/YOYO and $480 \mu \mathrm{L} 0.5 \mathrm{M} \mathrm{MES} \mathrm{of} \mathrm{pH}$ varying between 5.2 and 6.5 in a final volume of $1.4 \mathrm{~mL}$. Comb the $\lambda$ DNA and check for density of fibers and their stretching as described below. With $200 \mathrm{ng}$ of DNA, the coverslip should be densely covered with fibers. Use very small increments of $\mathrm{pH}$ for standardization (e.g., 0.05). Once the $\mathrm{pH}$ is standardized, use the optimum $\mathrm{pH}$ for melting sample plugs. Combing can vary substantially between $\mathrm{pH} 5.30$ and $\mathrm{pH}$ 5.35; a more basic $\mathrm{pH}$ gives fewer, but longer fibers on the coverslip and a more acidic $\mathrm{pH}$ allows more DNA of shorter length to stick on the coverslip but allows more stretching.

21. Incubate the plug for $20 \mathrm{~min}$ at $65^{\circ} \mathrm{C}$. Confirm that the plug has fully melted. If it has not, continue incubating for another $10 \mathrm{~min}$.

22. Transfer the plug to $42^{\circ} \mathrm{C}$ and incubate for $30 \mathrm{~min}$.

23. Add $40 \mu \mathrm{L} \beta$-agarase mix ( $4 \mu \mathrm{L} 10 \times$ NEB buffer, $4 \mu \mathrm{L} \beta$-agarase, $32 \mu \mathrm{L}$ sterile $\mathrm{H}_{2} \mathrm{O}$ ) to the tube. Digest overnight at $42^{\circ} \mathrm{C}$.

Do not mix after adding $\beta$-agarase. Gently swirl with a tip if needed. After digestion the samples should appear very clear. Usually, a small amount of wispy, thread-like agarose remnant is seen but there should be very few, if any, agarose clumps. If clumps are present, remelt the plug at $65^{\circ} \mathrm{C}$ and digest again with $\beta$-agarase mix. Improper cell wall digestion will make the plugs appear very cloudy and the $\beta$-agarase digestion will not occur optimally leading to poor DNA recovery.

24. Centrifuge the melted plug at $800 \mathrm{~g}$ for $5 \mathrm{~min}$ at room temperature. Handle the tubes with extreme care to avoid any damage to DNA fibers. 
25. Transfer the supernatant directly into the Teflon reservoir of a DNA Combing instrument (see Step 35) or, if the sample is to be stored for latter processing, into a new round-bottomed tube using a cut off $1 \mathrm{~mL}$ tip.

This supernatant is the DNA combing solution and there should be hardly any pellet. Use extreme care while transferring the supernatant to avoid DNA fiber breakage. The combing solution can be stored at $4^{\circ} \mathrm{C}$. However, with time the DNA fibers break; therefore, avoid storing for $>1 \mathrm{mo}$.

\section{Preparation of Silanized Coverslips for DNA Combing}

Coverslips are cleaned in a plasma cleaner such as a Harrick basic plasma cleaner. Liquid-based cleaning protocols can be used if a plasma cleaner is not available (Demczuk and Norio 2009; Marheineke et al. 2009).

\section{Plasma Cleaning of Coverslips}

26. Wash ceramic coverslip holders with water and then with ethanol. Allow to dry.

27. Place coverslips in ceramic holders without touching the flat surfaces of the coverslips.

28. Clean coverslips according to the instructions of the plasma cleaner manufacturer.

29. Quickly transfer coverslips to the desiccator for silanization.

After plasma cleaning, proceed immediately to silanization. Exposure of the coverslip to oxygen will lead to poor silanization.

\section{Silanization and Storage of Coverslips}

30. Place a $25 \mathrm{~mL}$ beaker in the center of the desiccator chamber.

Use a fresh beaker each time.

31. Add $1 \mathrm{~mL}$ octenyltrichlorosilane to the beaker.

Open the silane bottle, quickly take $1 \mathrm{~mL}$ and immediately close the bottle to minimize silane oxidization.

32. Evacuate the air from the desiccator by connecting it to a vacuum pump. The silane will begin to boil after the vacuum is established. Evacuate the desiccator for 2 min.

33. Seal the desiccator and allow silane coating to occur overnight.

34. Break the seal and remove the beaker containing remaining silane. Reseal the desiccator using the vacuum. Store the coverslips under vacuum until needed but use within $1 \mathrm{wk}$.

Combing

This protocol is based upon the DNA Combing System instrument from Genomic Vision, although other surfacecoating systems should work (Marheineke et al. 2009). Over 50 coverslips can be combed using the combing solution from one-half a plug.

35. Transfer the DNA combing solution very carefully (to avoid DNA breakage) into a Teflon reservoir.

To avoid breakage of DNA, after spinning the melted plug the supernatant can be transferred using a cut off $1 \mathrm{~mL}$ tip directly into the Teflon reservoir, instead of transferring it into a new tube and then into the reservoir.

36. Attach silanized coverslips to the instrument holder and dip it into the reservoir for $5 \mathrm{~min}$.

37. Withdraw the coverslips at a constant speed of $500 \mu \mathrm{m} / \mathrm{sec}$ to allow DNA molecules to stretch.

38. Check the density of fibers and stretching on the coverslips by epifluorescence using a GFP filter set and a 100× objective to visualize YOYO-1 stained DNA fibers. Select coverslips with wellstretched fibers of appropriate density for further analysis. Usually 5-10 coverslips will be suitable for further analysis.

The coverslips can be easily viewed with an inverted microscope. An upright microscope can also be used, but a coverslip holder is required to hold the coverslip DNA-side down while it is being viewed. Such a holder can be made by cutting a square hole in a thin piece of stiff plastic. 
D.R. Iyer et al.

39. Aspirate away the immersion oil from the coverslip. Place a drop of super glue on a slide. Place the coverslip oil-side down on the glue. Label the slide using pencil.

40. Incubate the slide for $2 \mathrm{~h}$ or overnight at $65^{\circ} \mathrm{C}$.

Baking robustly attaches DNA strands to the cover slip.

Proceed to Step 41 or Step 56.

Triple Staining (Two Analogs and ssDNA)

41. Cool slides for $5 \mathrm{~min}$ at room temperature. Place the slides in a Coplin jar. Denature the slides with freshly prepared $0.5 \mathrm{~N} \mathrm{NaOH}$ or $2.5 \mathrm{~N} \mathrm{HCl}$ for $30 \mathrm{~min}$; add acid or alkali and place the jar on a rocking platform.

The choice of denaturing agent, either $\mathrm{HCl}$ or $\mathrm{NaOH}$, depends on the batch of coverslips. Test the coverslip batch for optimal staining using spare labeled DNA before proceeding with test samples. Typically, CldU is best visualized using $\mathrm{HCl}$ denaturation. However, IdU staining does not work well with $\mathrm{HCl}$ denaturation. $I d U$ is best visualized using $\mathrm{NaOH}$ denaturation, while CldU staining is moderate. At low concentrations, $\mathrm{CldU}$ staining is quite punctate, which can complicate analysis. At high CldU concentrations, $\mathrm{NaOH}$ gives good results.

42. Transfer the slides to a fresh Coplin jar and wash the slides with $0.1 \times$ PBS three times for $5 \mathrm{~min}$ each on a rocking platform.

43. Place the slides in a humid chamber (box containing wet paper towels).

44. Block coverslips with $1 \%$ BSA by adding $50 \mu \mathrm{L}$ of solution per coverslip. Place a second coverslip on top of each to spread out the solution and to prevent evaporation. Incubate the box for $25 \mathrm{~min}$ at $37^{\circ} \mathrm{C}$.

Apply fresh top coverslips as described in Step 44 for all subsequent antibody incubations.

45. Remove the top coverslip by dipping the slide horizontally in a wide chamber containing $0.1 \times$ PBST. Wash the slides with $0.1 \times$ PBST twice for 2 min each.

Remove top coverslips as described in Step 45 for all subsequent washes. In most cases the top coverslip will float off easily; however, it may be necessary to gently ease it off using a micropipette tip.

46. Add $50 \mu \mathrm{L} \mathrm{CldU} \mathrm{(rat)} \mathrm{and} \mathrm{IdU} \mathrm{(mouse)} \mathrm{primary} \mathrm{antibodies.} \mathrm{Incubate} \mathrm{for} 1 \mathrm{~h}$ at $37^{\circ} \mathrm{C}$.

47. Wash the slides with $0.1 \times$ PBST twice for 3 min each.

48. Add anti-rat 594 and anti-mouse 488 antibodies. Incubate for $30 \mathrm{~min}$ at $37^{\circ} \mathrm{C}$.

49. Wash the slides with $0.1 \times$ PBST twice for 3 min each.

50. Add rabbit anti-ssDNA primary antibody. Incubate for $1 \mathrm{~h}$ at $37^{\circ} \mathrm{C}$.

51. Wash the slides with $0.1 \times$ PBST twice for 3 min each.

52. Add anti-rabbit 350 . Incubate for $30 \mathrm{~min}$ at $37^{\circ} \mathrm{C}$.

53. Wash the slides with $0.1 \times$ PBST twice for 3 min each.

54. Drain off excess $0.1 \times$ PBST. Add $18 \mu \mathrm{L}$ of anti-fade mounting medium per coverslip. Place a top coverslip on each and seal with nail polish. Allow the nail polish to dry before visualization.

If using ProLong Gold Antifade, allow the slides to cure for $24 \mathrm{~h}$ at room temperature before sealing with nail polish.

55. Keep slides at $-20^{\circ} \mathrm{C}$ for long-term storage.

Double Staining (Single Analog and ssDNA)

56. Follow the same protocol as for triple staining (Steps 41-55), except at Step 46 add a single primary antibody instead of both and similarly add a single secondary antibody at Step 48.

Addition of analog and ssDNA primary antibodies together may compromise analog staining; therefore, add them sequentially. ssDNA can be visualized better in 488 and 594 channels as opposed to 350. Therefore, depending on the secondary antibody used for the analog, either Alexa fluor 488 or 594 labeled antibodies can be used for ssDNA visualization rather than an Alexa fluor 350 labeled antibody. 
Blocking Buffer for DNA Combing

$1 \%$ BSA (fraction V)

$0.1 \times$ PBS (pH 7.4) (diluted from stock PBS [10×; $\mathrm{pH} 7.4]<\mathrm{R}>$ )

$0.05 \%$ Tween 20

Prepare fresh for each application.

DNA Combing Enzyme Mix

Reagent

Volume

Spheroplasting buffer $<\mathrm{R}>$

$1910 \mu \mathrm{L}$

Zymolyase $20 \mathrm{~T}(20 \mathrm{mg} / \mathrm{mL})$

$40 \mu \mathrm{L}$

Lysing enzyme (Sigma-Aldrich L1412; 25 mg/mL)

$40 \mu \mathrm{L}$

$\beta$-mercaptoethanol

$10 \mu \mathrm{L}$

Make fresh for each application.

DNA Combing Plug Solution

$\begin{array}{ll}\text { Spheroplasting buffer }<\mathrm{R}> & 1 \mathrm{~mL}\end{array}$

Zymolyase 20T

$10 \mathrm{mg}$

Lysing enzyme (Sigma-Aldrich L1412)

$12 \mathrm{mg}$

$\beta$-mercaptoethanol

$10 \mu \mathrm{L}$

Make fresh for each application.

\section{PBST for DNA Combing}

$0.1 \times$ PBS (pH 7.4) (diluted from stock PBS [10×; $\mathrm{pH} 7.4]<\mathrm{R}>$ )

$0.05 \%$ Tween 20

Store at room temperature.

Proteinase K Buffer

Reagent

Volume

EDTA $(0.5 \mathrm{~m}, \mathrm{pH} 8)$

$1 \mathrm{~mL}$

SDS $(20 \%)$

$0.5 \mathrm{~mL}$

Proteinase $\mathrm{K}$ enzyme $(20 \mathrm{mg} / \mathrm{mL}$ stock $)<\mathrm{R}>$

$0.25 \mathrm{~mL}$

Sterile $\mathrm{H}_{2} \mathrm{O}$

$8.5 \mathrm{~mL}$

Make fresh for each application.

Proteinase K Enzyme (20 mg/mL Stock)

Reagent

Volume

Tris $(1 \mathrm{M}, \mathrm{pH} 8.0)$

$50 \mu \mathrm{L}$

$\mathrm{CaCl}_{2}(1 \mathrm{M})$

$5 \mu \mathrm{L}$

Glycerol (60\%)

$2.5 \mathrm{~mL}$

Proteinase $\mathrm{K}$

$100 \mathrm{mg}$

Sterile $\mathrm{H}_{2} \mathrm{O}$

$2.5 \mathrm{~mL}$

Store in aliquots at $-20^{\circ} \mathrm{C}$. 
D.R. Iyer et al.

PBS (10×; $p H 7.4)$

$320 \mathrm{~g} \mathrm{NaCl}$

$8 \mathrm{~g} \mathrm{KCl}$

$57.6 \mathrm{~g} \mathrm{Na}_{2} \mathrm{HPO}_{4}$

$9.6 \mathrm{~g} \mathrm{KH}_{2} \mathrm{PO}_{4}$

Dissolve in $3 \mathrm{~L}$ of distilled $\mathrm{H}_{2} \mathrm{O}$. Adjust the $\mathrm{pH}$ to 7.4. Bring to $4 \mathrm{~L}$ with distilled $\mathrm{H}_{2} \mathrm{O}$. Autoclave.

Store at room temperature indefinitely.

Spheroplasting Buffer

Reagent Volume

Citrate phosphate $(0.2 \mathrm{M}, \mathrm{pH} 5.6)$

$5 \mathrm{~mL}$

EDTA (0.5 M, pH 8.0)

$5 \mathrm{~mL}$

Sorbitol $(2 \mathrm{M})$

$25 \mathrm{~mL}$

Sterile $\mathrm{H}_{2} \mathrm{O}$

$15 \mathrm{~mL}$

Store for up to $1 \mathrm{mo}$ at room temperature.

TE Buffer

Reagent Quantity (for $100 \mathrm{~mL}$ )

Final concentration

EDTA (0.5 M, pH 8.0)

Tris-Cl (1 M, pH 8.0)

$\mathrm{H}_{2} \mathrm{O}$

$0.2 \mathrm{~mL}$

$1 \mathrm{~mL}$

to $100 \mathrm{~mL}$

Yeast Extract with Supplements (YES)

Reagent

Amount to add (1 L)

Glucose

$30 \mathrm{~g}$

Yeast extract

$5 \mathrm{~g}$

Adenine

$0.2 \mathrm{~g}$

Uracil

$0.2 \mathrm{~g}$

Histidine

$0.2 \mathrm{~g}$

Leucine

$0.2 \mathrm{~g}$

Lysine

$0.2 \mathrm{~g}$

Agar (for solid medium only)

$20 \mathrm{~g}$

$\mathrm{H}_{2} \mathrm{O}$

to $1 \mathrm{~L}$

Prepare $1 \mathrm{~L}$ of YES by combining the reagents listed above. Sterilize by autoclaving at 10 psi for $15 \mathrm{~min}$. Store at $4^{\circ} \mathrm{C}$. (Note that the yeast extract contains sufficient thiamine to repress $n m t 1$ promoters.)

We thank Atanas Kaykov for critical information regarding the preparation of silanized combing surfaces and for highlighting the importance of MES $\mathrm{pH}$ to facilitate isolation of long DNA fibers.

\section{REFERENCES}

Demczuk A, Norio P. 2009. Determining the replication dynamics of specific gene loci by single-molecule analysis of replicated DNA. Methods Mol Biol 521: 633-671.
Gallo D, Wang G, Yip CM, Brown GW. 2016. Analysis of replicating yeast chromosomes by DNA combing. Cold Spring Harb Protoc doi: 10.1101/ pdb.prot085118. 
DNA Combing in Fission Yeast

Hodson JA, Bailis JM, Forsburg SL. 2003. Efficient labeling of fission yeast Schizosaccharomyces pombe with thymidine and BUdR. Nucleic Acids Res 31: e134.

Marheineke K, Goldar A, Krude T, Hyrien O. 2009. Use of DNA combing to study DNA replication in Xenopus and human cell-free systems. Methods Mol Biol 521: 575-603.
Sivakumar S, Porter-Goff M, Patel PK, Benoit K, Rhind N. 2004. In Vivo labeling of fission yeast DNA with thymidine and thymidine analogs. Methods 33: 213-219. 


\section{Analysis of DNA Replication in Fission Yeast by Combing}

Divya R. lyer, Shankar Das and Nick Rhind

Cold Spring Harb Protoc; doi: 10.1101/pdb.prot092015 originally published online July 21, 2017

\begin{tabular}{|c|c|}
\hline $\begin{array}{r}\text { Email Alerting } \\
\text { Service }\end{array}$ & Receive free email alerts when new articles cite this article - click here. \\
\hline $\begin{array}{l}\text { Subject } \\
\text { Categories }\end{array}$ & $\begin{array}{l}\text { Browse articles on similar topics from Cold Spring Harbor Protocols. } \\
\text { Antibodies ( } 119 \text { articles) } \\
\text { Fluorescence (517 articles) } \\
\text { Genomic DNA (135 articles) } \\
\text { Immunodetection ( } 34 \text { articles) } \\
\text { Immunofluorescence (51 articles) } \\
\text { Molecular Biology, general (1293 articles) } \\
\text { Yeast (288 articles) } \\
\text { Yeast Genetics (135 articles) }\end{array}$ \\
\hline
\end{tabular}

